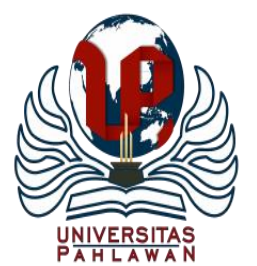

Jurnal Basicedu Volume 5 Nomor 1 Tahun 2021 Halaman 456-463

JURNAL BASICEDU

Research \& Learning in Elementary Education

https://jbasic.org/index.php/basicedu

\title{
Analisis Model Cooperative Learning Tipe Student Team Achievement Division terhadap Hasil Belajar Matematika Masa Pandemi COVID-19
}

\author{
Sindy April Lia Eka Putri ${ }^{1}$, Anggy Giri Prawiyogi ${ }^{2}$, Andes Safarandes Asmara ${ }^{3}$ \\ Universitas Buana Perjuangan, Indonesia ${ }^{1,2,3}$, \\ E-mail: Sd16.Sindyputri@ mhs.ubpkarawang.ac.id ${ }^{1}$, anggy.prawiyogi@ubpkarawang.ac.id ${ }^{2}$, \\ Andes.Asmara@ubpkarawang.ac.id ${ }^{3}$
}

\begin{abstract}
Abstrak
Pada tahun 2019 ditemukan wabah penyakit yang berasal dari China yaitu Corona Virus atau COVID 19 yang menyebar dengan cepat ke seluruh dunia. Penyebaran virus ini sangat merugikan Negara khususnya dalam bidang pendidikan di Indonesia. Keberadaan lembaga pendidikan COVID-19 di Indonesia pada masa liburan sangat berpengaruh dalam proses pembelajaran di sekolah, banyak sekolah yang menerapkan pembelajaran online atau E-learning. Di bidang pendidikan masih banyak sekolah yang ditutup dan diganti dengan pembelajaran online, namun ada juga sekolah yang melaksanakan pembelajaran dengan membuat kelompok kecil. Model pembelajaran dalam kelompok dapat membantu siswa lebih mudah memahami materi pembelajaran karena adanya proses interaksi antar siswa dan interaksi dengan guru. Model pembelajaran yang dapat diterapkan dalam pembelajaran kelompok adalah model pembelajaran kooperatif STAD (Student Team Achievement Division), penerapan model pembelajaran ini dapat meningkatkan hasil belajar siswa.
\end{abstract}

Kata kunci : Model Pembelajaran, Hasil Belajar siswa, Pandemi COVID-19

\begin{abstract}
In 2019, an outbreak of a disease originating from China, namely CoronaVirus or COVID 19, was found which spread rapidly throughout the world. The spread of this virus is very detrimental to the State, especially in the field of education in Indonesia. The existence of COVID-19 education institutions in Indonesia on vacation is very influential in the learning process in schools, many of the schools are implementing online learning or E-learning. In the field of education, there are still many schools that have been closed and replaced with online learning, but there are also schools that implement learning by creating small groups. The learning model in groups can help students more easily understand the learning material due to the interaction process between other students and the interaction with the teacher. The learning model that can be applied in group learning is the STAD (Student Team Achievement Division) cooperative learning model, applying this learning model can improve student learning outcomes.
\end{abstract}

Keywords: Learning Model, Student Learning Outcomes, COVID-19 Pandemic

Copyright (c) 2021 Sindy April Lia Eka Putri, Anggy Giri Prawiyogi, Andes Safarandes Asmara

$\triangle$ Corresponding author

Address :-

Email : anggy.prawiyogi@ubpkarawang.ac.id

ISSN 2580-3735 (Media Cetak)

Phone :-

ISSN 2580-1147 (Media Online)

DOI : https://jbasic.org/index.php/basicedu/article/view/785 
457 Analisis Model Cooperative Learning Tipe Student Team Achievement Division terhadap Hasil Belajar Matematika massa Pandemi COVID-19 - Sindy April Lia Eka Putri, Anggy Giri Prawiyogi, Andes Safarandes Asmara

DOI : https://jbasic.org/index.php/basicedu/article/view/785

\section{PENDAHULUAN}

Pada Tahun 2019 ditemukan wabah penyakit yang berasal dari Cina, yaitu Corona Virus atau COVID 19 yang menyebar dengan cepat ke seluruh Dunia."Covid 19 dapat menyebabkan penyakit yang dapat menimbulkan gejala berat seperti hannya Middle East Respiratory Syndrome (MERS) dan Severe Acute Respiratory Syndrome (SARS)" (Kementerian Kesehatan, 2020).Wabah COVID-19 juga melanda di Indonesia pada awal Maret 2020 COVID-19, virus tersebut semakin meluas melanda di Indonesia hingga sampai saat ini ribuan orang terjangkit COVID-19. Adanya COVID-19 instansi Pendidikan di Indonesia di liburkan sangat berpengaruh dalam proses pembelajaran di Sekolah, banyak dari sekolah yang menerapkan pembelajaran melalui online atau E-learning, Namun pada saat proses pembalajaran secara online terdapat berbagai macam kekurang diantaranya fasilitas yang belum memadai yang di miliki oleh siswa dan guru seperti akses internet, computer atau leptop dan smart handphone.Sehingga proses pembelajaran secara online belum berjalan dengan sempurna. Proses pembelajaran yang belum sempurna dapat menggangu dari tujuan Pendidikan itu sendiri dikarenakan dalam Pendidikan nasional Indonesia yang di atur dalam UUD Negara Republik Indonesia Tahun 1945, winataputra dkk (2011:1.5) bahwa "tujuan Pendidikan nasional tentang sistem Pendidikan nomor 20 tahun 2003 adalah menjadikan peserta didik yang berahklak mulia dalam bermasyarakat, mempunyai ilmu yang tinggi, cakap dalam menentukan pilihan atau tindakan hidup, mempunyai kreativitas, menjadi manusia yang mandiri dan dapat menjadi warga negara yang baik".
Pada Tahun ajaran Baru 2020/2021 Pemerintah Indonesia menetapkan sistem New Normal dalam semua bidang temasuk bidang Pendidikan, dalam bidang Pendidikan masih banyak sekolah yang di tutup dan di ganti dengan pembelajaran online, namun juga ada sekolah yang menerapkan pembelajaran dengan membuat kelompok-kelompok kecil agar walaupun proses pembelajaran online masih ada sesi tatap muka dengan guru dengan bertujuan siswa masih merasakan susasa bersekolah dan agar lebih mudah memahami materi pembelajaran dan tujuan pembelajaran tercapai. Akibat proses libur sekolah yang lama dan pembelajaran secara online ditemukan siswa yang sudah lupa akan materi yang di sampaikan oleh guru pada waktu sebelum masa pandemik COVID-19, khususnya pada pembelajaran Matematika.

Permasalahn ini ditemukan pada saat proses kegiatan belajar secara berkelompok yang dilakukan oleh siswa di SDN Anggadita 1 kelas 5. Dalam proses kegiatan pembelajaran sekolah membagi tiap kelas menjadi kelompok- kelompok kecil dengan beranggotaan setiap kelompok 5 siswa dengan secara bergilir guru mendatangi kelompok belajar tersebut, pada saat pertemuan pertama dalam proses kegiatan belajar tersebut guru mengulang Kembali pembelajaran yang terlewatkan oleh siswa , banyak dari siswa tersebut yang tidak mampu menjawab pertanyakan yang di buat oleh guru dikarenakan banyak siswa yang lupa akan materi yang telah di sampaikan atau telah dipelajari. Dari hasil observasi peneliti di kelompok belajar kelas 5 masih banyak siswa yang mendapatkan hasil belajar yang di bawah KKM (Kriteria Ketuntasan Minimal), Dalam proses pembelajaran masih banyak siswa yang kurang fokus terhadap materi yang 
disampaikan oleh guru. Guru masih menggunakan metode pembelajaran ceramah sehingga siswa merasa bosan dan sulit memahami materi yang disampaikan dan banyak siswa yang lupa akan materi yang telah dipelajari.

Berdasarkan penjelasan diatas peneliti mengunakan model pembelajran cooperative learning tipe STAD (Student Team Achievement Division) terhapat proses pembelajaran berkelompok siswa kelas 5siswa untuk meningkatkan hasil belajar. Hal inilah yang mendorong penulis untuk melakukan penelitian dengan permasalahan "Analisis Model Pembelajaran cooperative learning tipe STAD (Student Team Achievement Division) terhadap hasil belajar Matematika dalam masa pandemi COVID-19

\section{METODE}

Penelitian ini menggunkan metode penelitiankualitatif deskriptif. Adapun yang dimaksud penelitian kualitatif Meleong (2007:6) "yaitu penelitian yang bermaksud memahami fenomena tentang apa yang di alami oleh subjek penelitian secara holistik, dan dengan cara deskripsi dalam bentuk kata kata dan bahasa, dalam suatu konteks khusu yang alamiah dan dengan memanfaatkan sebagai metode ilmiah".

Penilitian ini dilakukan di SDN Anggadita 1 yang beralamat di desa Anggadita, Kecamatan Klari, Kabupaten Karawang. Waktu penilitian ini dilakukan pada bulan Januari sampai dengan Juli 2020.

Subjek penelitian ini adalah siswa kelas V SDN Anggadita 1 Kecamatan Klari Kabupaten Karawang yang merupakan informan utama. Pemilihan subjek dilakukan dengan cara memilih sample dari beberapa siswa kelas V sebagai sumber dari penelitian.
Arikunto (2002:136) berpendapat bahwa "metode penelitian adalah berbagai cara yang digunakan peneliti dalam mengumpulkan data penelitiannya". Cara yang dimaksud adalah wawancara, dan studi dokumentasi. Teknik pengumpulan data disesuaikan dengan jenis data yang dibutuhkan pada penelitian ini sebagai berikut.

Observasi atau pengamatan yang dilakukan pada suatu objek tertentu. "Dari segi proses pelaksanaan pengumpulan data, observasi dapat dibedakan menjadi participant observation (observasi berperanserta) dan nonparticipant observation (observasi non partisipan). Selanjutnya dari segi instrumen yang digunakan, observasi dibedakan menjadi observasi terstruktur dan tidak terstruktur. Dalam penelitian ini, peneliti menggunakan observasi nonpartisipan karena peneliti tidak terlibat dan hanya sebagai pengamat independent" (Sugiyono, 2010:204).

Pada observasi dalam penelitian ini menggunakan observasi secara langsung ke lapangan dengan mengikuti kegiatan pembelajaran kelompok belajar kelas V SDN Anggadita 1.

Wawancara Merupakan percakapan yang dilakukan antara 2 orang atau lebih dengan tujuan mencari sumber data yang diperluhkan. Sudijono (1996: 82) " adabeberapa kelebihan pengumpulan data melalui wawancara, diantaranya pewawancara dapat melakukan kontak langsung dengan peserta yang akan dinilai, data diperoleh secara mendalam, yang diinterview bisa mengungkapkan isi hatinya secara lebih luas, pertanyaan yang tidak jelas bisa diulang dan diarahkan yang lebih bermakna".

Dalam penelitian ini peneliti melakukan wawancara terhadap guru kelas V SDN Anggadita 1 sebagai narasumber dan 
beberapa siswa sebagai narasumber untuk memperoleh data yang lebih akurat.

"Metode dokumentasi adalah mencari data yang berupa catatan, transkrip, buku, surat kabar, majalah, prasasti, notulen rapat, legger, agenda dan sebagainya" (Arikunto, 2002:206). Arikanto (2006,158)“Dokumentasi adalah mencari dan mengumpulkan data mengenai hal-hal yang berupa catatan, transkip, buku, surat kabar, majalah, notulen, rapot, agenda dan sebagainya".

Dalam penelitian ini peneliti menggunakan dokumentasi berupa soal latihan yang digunakan untuk mengukur pengaruh antrara metode dengan hasil belajar dan traskrip nilai siswa.

"Tes dapat berupa serentetan pertanyaan, lembar kerja, atau sejenisnya yang dapat digunakan untuk mengukur pengetahuan, keterampilan, bakat, dan kemampuan dari subjek penelitian. Lembar instrumen berupa tes ini berisi soal-soal ter terdiri atas butirbutir soal. Setiap butir soal mewakili satu jenis variabel yang diukur. Berdasarkan sasaran dan objek yang diteliti, terdapatt beberapa macam tes, yaitu:

Tes kepribadian atau personality test, digunakan untuk mengungkap kepribadian seseoranng yang menyangkut konsep pribadi, kreativitas, disiplin, kemampuan, bakat khusus, dan sebagainya

Tes bakat atau aptitude test, tes ini digunkan untuk mengetahui bakat seseorang.

Tes inteligensi atau intelligence test, dilakukan untuk memperkirakan tingkat intelektual seseorang.

Tes sikap atau attitude test, digunakan untuk mengukur berbagai sikap oranng dalam menghadapi suatu kondisi,
Tes minat atau measures of interest, ditunjukan untuk menggali minat seseorang terhadap sesuatu,

Tes prestasi atau achievement test, digunakan untuk mengetahui pencapaian sesorang setelah dia mempelajari sesuatu.

Dalam penelitian ini peneliti menggunakan tes berupa latihan soal untuk mengukur tinggak keberhasilan siswa.

Moleong ( 2007:330) "Penelitian kualitatif harus mengungkap kebenaran yang objektif. Karena itu keabsahan data dalam sebuah penelitian kualitatif sangat penting. Melalui keabsahan data kredibilitas (kepercayaan) penelitian kualitatif dapat tercapai. Dalam penelitian ini untuk mendapatkan keabsahan data dilakukan dengan triangulasi. Adapun triangulasi adalah teknik pemeriksaan keabsahan data yang memanfaatkan sesuatu yang lain di luar data itu untuk keperluan pengecekan atau sebagai pembanding terhadap data". Untuk memeriksa keabsahan data dalam penelitian ini, peneliti menggunakan teknik triangulasi.

Triangulasi dengan sumber yang dilaksanakan pada penelitian ini yaitu membandingkan hasil wawancara dengan isi dokumen yang berkaitan.

Triangulasi Teknik.Menurut Sugiyono (2010: 330) triangulasi teknik berarti peneliti menggunakan teknik pengumpulan data yang berbeda-beda untuk mendapatkan data dari sumber data yang sama.

$$
\text { Triangulasi Sumber }
$$

Sugiyono(2010:330)triangulasi sumber "berarti untuk mendapatkan data dari sumber yang berbeda-beda dengan teknik yang sama".

Teknik Analisis Data. Moleong (2007: 248) Menurut Bogdan \& Biklen, analisis data kualitatif adalah "upaya yang dilakukan dengan jalan bekerja dengan data, 
mengorganisasikan data, memilih-milihnya menjadi satuan yang dapat dikelola, mensintesiskannya, mencari dan menemukan pola, menemukan apa yang penting dan apa yang dipelajari, dan memutuskan apa yang dapat diceritakan kepada orang lain".

"Data yang muncul dalam wujud katakata dan bukan angka dikumpulkan melalui berbagai cara seperti observasi, wawancara, intisari dokumen, pita, rekaman biasanya diproses melalui pencatatan, pengetikan, penyuntingan, atau alih-tulis" (Miles dan Huberman, 1992: 15).

"Mereduksi data berarti merangkum, memilih hal-hal yang pokok, memfokuskan pada hal-hal yang penting, dan dicari tema dan polanya, sebab data yang diperoleh dari lapangan jumlahnya cukup banyak dan perlu dicatat secara teliti dan rinci. Dengan melakukan reduksi data akan memberikan gambaran yang lebih jelas, mempermudah peneliti untuk melakukan pengumpulan data selanjutnya, dan mencarinya bila diperlukan. Reduksi data dapat dilakukan dengan bantuan komputer dengan memberikan kode pada aspek-aspek tertentu"(Sugiyono, 2016: 247).

"Setelah data direduksi, langkah selanjutnya adalah mendisplaykan data. Dalam penelitian kualitatif, penyajian data bisa dilakukan dalam bentuk uraian singkat, bagan, hubungan antar kategori, flowchart, dan sejenisnya. Yang paling sering digunakan untuk menyajikan data dalam penelitian kualitatif adalah dengan teks yang bersifat naratif' (Sugiyono, 2016: 249).

Conclusion drawing (Penarikan kesimpulan/verifikasi) Langkah ketiga adalah penarikan kesimpulan dan verifikasi. Penarikan kesimpulan dilakukan dengan menemukan makna data yang telah disajikan.
Dari data-data yang telah terkumpul selanjutnya dilakukan penarikan kesimpulan.

\section{HASIL PENELITIAN DAN PEMBAHASAN}

Dari hasil penelitian yang telahdilakukan dalam proses penerapan Model pembelajaran cooperative learning tipe STAD terhadap hasil belajar matematika untuk kelompok belajar kelas VB SDN Anggadita 1. Guru menerapkan model tersebut dengan bertujuan untuk meningkatkan hasil belajar siswa dikarenakan untuk model pembelajaran cooperative learning tipe STAD merupakan metode yang model pembelajarannya mengelompokan siswa menjadi beberapa kelompok yang dipilih oleh guru berdasarkan hasil prestasi siswa agar siswa saling membantu dan adanya interaksi berdiskusi antara guru dan siswa.

Dalam penerapan model pembelajaran Cooperative Learning tipe STAD membutuhkan peran aktif dari guru dan siswa, sehingga akan menimbulkan interaksi yang baik antara guru dan siswa. Dalam proses penyampaian materi yang dilakukan guru tidak semua menggunakan media ceramah saja dan siswa hannya mendengarkan tapi guru melibatkan peran siswa untuk membahasa materi yang sedang di pelajari, dengan guru melibatkan peran siswa maka guru merasa lebih yakin bahwa siswa benar-benar mampu memahami materi-materi yang disampaikan dan dibahas secara bersama-sama dibandingkan hannya guru saja yang membahas materinya. Dari hasil pembelajaran menggunakan model pembelajaran Cooperative Learning tipe STAD ditemukan : ada beberapa aspek yang di amati yaitu : Aspek penyiapan siswa, Aspek penyampaian materi, Aspek penggunakan model pembelajaran, Aspek keaktifan siswa, dan Aspek hasil belajar siswa 
461 Analisis Model Cooperative Learning Tipe Student Team Achievement Division terhadap Hasil Belajar Matematika massa Pandemi COVID-19 - Sindy April Lia Eka Putri, Anggy Giri Prawiyogi, Andes Safarandes Asmara

DOI : https://jbasic.org/index.php/basicedu/article/view/785

Pada aspek penyiapan siswa yang telah dilakukan oleh guru kelas VB Ibu Yuli Wiyati sudah menyiapkan siswa dengan baik dari fisik maupun psikis siswa dengan kegiatan, Berdoa, mengondisikan siswa untuk melakukan kegiatan pembelajaran, menanyakan kabar siswa, mengabsen siswa, dengan tujuan untuk memberikan perhatian dan motivasi guru kepada siswa. Idris (dalam Haerudin, 2010:276) berpendapat bahwa " kegiatan guru pada awal pelajaran adalah menyiapkan siswa pada materi yang akan dipelajarai, pada pernyataan tersebut jika siswa kelas VB tida disipakan terlebih dahulu maka proses pembelajaran akan tidak berjalan dengan baik".

Pada aspek penyamapaian materi yang dilakukan guru kelas VB Ibu Yuli Wiyati sudah menyamapaikan dengan baik dan jelas. Marno( dalam kesuma, 2010:96) mengatakan bahwa "pada dasarnya penyampaian materi adalah menuturkan materi secara jelas dan sistematis sehingga memudahkan siswa untuk memahami pembelajaran.

Aspek penggunakan model pembelajaran cooperative learning tipe STAD yang telah dilakukan Ibu Yuli wiyati dalam pembelajarannya sudah mengikuti tahapantahapan dalam pembelajaran cooperative learning tipe STAD yaitu dengan tahapan persiaapan siswa, penyampaian materi, pembagian kelompok, pemberia tugas atau latihan soal, bimbingan kepada siswa, penilaian da evaluasi dari hasil belajar siswa, sesuai dengan tahapan dari Slavina( dalam slomo, 210:6) menjelaskan tahapan fase cooperative learning tipe STAD yaitu :

Guru presentasi, memberikan materi yang akan dipelajari secara garis besar dan prosedur kegiatan, juga tata cara kerja kelompok.
Guru membentuk kelompok, berdasarkan kemampuan siswa, jeni kelamin, ras, suku dan jumlahnya diantara 3-5 orang siswa.

Siswa bekerja dalam kelompok, siswa belajar bersama, diskusi atau mengerjakan tugas yang diberikan guru sesuai LKS.

Scafolding, guru memberikan bimbingan.

Validation, guru mengadakan validasi hasil kerja kelompok dan memberikan kesimpulan tugas kelompok.

Quizzes, guru mengadakan kuis secara individu, hasil nilai dikumpulkan, dirata-rata dalam kelompok, selisih skor awal (basescore ) individu dengan skor hasil kuis (skor perkembangan).

Penghargaan kelolmpok, berdasarkan skor perhitungan yang diperoleh anggota, dirata-rata, hasilnya disesuaikan dengan predikat tim.

Evaluasi yang dilakukan oleh guru

Pada aspek keaktifan siswa kelas VB ada beberapa siswa yang aktif mengikuti proses pembelajaran dengan menggunakan model pembelajaran cooperative learning, keaktivan siswa dapat dilihat dari hasil belajar siswa dan proses pembelajaran seperti kegiatan tanya jawab, tetapi ada beberapa siswa yang mendapatkan hasil belajar yang maksimal namun tidak aktif dalam kegtan tanya jawab. Hartono (dalam kesuma, 2008:20) keaktifan siswa yaitu "suatu pembelajaran yang mengajak siswa untuk belajar secara aktif.

Pada aspek hasil belajar siswa kelas VB pada materi volume bangun ruang dan balok rata- rata siwa mendapatkan hasil belajar yang maksimal yaitu diatas KKM dikarenakan Siswa mampu menyelesaikan masalah yang berkaiatan dengan bangun ruag balok dan 
462 Analisis Model Cooperative Learning Tipe Student Team Achievement Division terhadap Hasil Belajar Matematika massa Pandemi COVID-19 - Sindy April Lia Eka Putri, Anggy Giri Prawiyogi, Andes Safarandes Asmara

DOI : https://jbasic.org/index.php/basicedu/article/view/785

kubus. Sudjana (dalam kesuma 2012:22) berpendapat bahwa "hasil belajar adalah proses kegiatan belajar akan menghasilkan hasil belajar sebagai penentu peserta didik dapat memahami atau menguasai materi yang telah dipelajari

Dalam proses pembelajaran ditemukan kekurangan dalam model pembelajaran cooperative learning tipe STAD yaitu:

Beberapa siswa tidak memperhatikan guru pada saat guru menjelaskan materi

Beberapa Siswa tidak aktif menjawab pertanyaan dari guru hannya Sebagian siswa yang aktif menjawab pertanyan yang di berikan oleh guru

Ketika guru memberikan kesempatan siswa untuk bertanya sebagian besar siswa hanya terdiam dan hannya beberapa siswa yang aktif untuk bertanya

Pada saat guru memberikan tugas individu kepada siswa banyak diantara siswa yang tidak bisa menjawab soal yang diberikan oleh guru

Pada saat guru meberikan tugas kelompok berupa latihan soal hannya sebagian siswa saja yang menengerjakan sisanya hannya melihat jawaban dari temannya saja.

Siswa mengandalkan temannya yang dianggap pintar sehinggnya temannya yang lain hannya melihat jawaban temannya saja tanpa berdiskusi terlebih dahulu

\section{KESIMPULAN}

Dari hasil penelitian yang telah dilakukan peneliti dapat disimpulkan bahwa penerapan model pembelajaran cooperative learning tipe STAD dapat meningkatkan hasil belajar siswa dalam pembelajaran matematika materi volume bangun ruang balok dan kubus pada kelas VB SDN Anggadita 1 Kecamatan Klari dapat disimpulka sebagai berikut :
Peningkatan hasil belajar siswa terjadi pada hasil belajar latihan soal materi volume bangun ruang balok dan kubus siswa mendapatkan hasil rata-rata diatas $\mathrm{KKM}$ walaupun situasi pembelajaran ditengah masa pandemi COVID-19.

Langkah - Langkah pembelajaran menggunakan model pembelajaran cooperative learning tipe STAD dapat membantu siswa untuk saling bekerjasama dan berikteraksi untuk menyelesaikan masalah

\section{DAFTAR PUSTAKA}

Sharan, Shlomo (2012) Cooperative Learning. Istana Media.Yogyakarta

Fitri Ayu,2018,Model Pembelajaran Matematika Di Sekolah Dasar,FBIS Publishing,karawang

Sukamiyati. 2014.Meningkatkan Hasil Belajar Maematika Melalui Penidikan Matematika Realistik( PMR ) Pada Siswa Kelas IV SDN Timbulharjo.Yogyakarta. Jurusan Pra Sekolah Dan Sekolah Dasar Fakultas Ilmu Pendidikan UNY Yogyakarta

Syarif, Mohammad, Sumantri,2015.Strategi Pembelajajaran,PT Rajagrafindo persada,Jakarta

Haerudin .(2016). Penerapan Pembelajaran Kooperatif Tipe Student Teams Achievement Division (STAD) Terhadap Hasil BelajarPI Di Sekolh Dasar. Jurnal Sekolah Dasar ISSN 2528 -2883 Vol.1 No.1

Windiyana, Ericha Pratiwi (2020), Dampak COVID-19 Terhadap Kegiatan Pembelajaran Online Di Sebuah Perguruan Tinggi Kristen Di Indonesia. Jurnal Perspektif Ilmi Pendidikan Vol. 34 No.1 April 2020 
463 Analisis Model Cooperative Learning Tipe Student Team Achievement Division terhadap Hasil Belajar Matematika massa Pandemi COVID-19 - Sindy April Lia Eka Putri, Anggy Giri Prawiyogi, Andes Safarandes Asmara

DOI : https://jbasic.org/index.php/basicedu/article/view/785

Alvani. (2016). Profil Kreativitas Siswa SMP dalam Menyelesaikan Soal. p-ISSN: 2086-2334; e-ISSN: 2442-4218, 173.

Kesuma, M. D. (2013).Peningkatan Aktivitas Dan HasilBelajar Siswa SMP. Jurnal Pendidikan Fisika, 4.

Masdalilah. (2016). Meningkatkan Hasil BelajarMatematika Dengan Model STAD Di Kelas VI SD NEGERI NO. 028 LUMBAN DOLOK. p-ISSN: 2355 - 1739, 127.

Nurhazannah,Y.(2017).Meningkatkan Hasil Belajar SiswaMenggunakan Model PembelajaranKooperatif.Jurnal Pendidikan Matematika dan IPA Vol. 8 No. 2 Juli 2017: 50-59, 50-59

Lestari, k., \& yudhanegara, m. (2018).Penelitian Pendidikan Matematika

Sugiyono. (2015). Metode Peneliian Kuantitatif, Kualitatif Dan R\&D. Bandung: Alfabeta.

Yusuf, M. 2014.Metode Peneliian Kuantitatif, Kualitatif \& Peneliian Gabungan.Jakarta: Prenadamedia Group

Susanto, A. (2013). Teori Belajar dan Pembelajaran Di Sekolah Dasarjakarta: Kencana prenada media group.

Susanto, A. (2016).Teori Belajar dan Pembelajaran Di Sekolah Dasar. Jakarta: Kencana Prenada 